\title{
KORPUS STRAŻY SKARBOWEJ REPUBLIKI WŁOSKIEJ. WYBRANE ZAGADNIENIA
}

DOI: http://dx.doi.org/10.12775/TSP-W.2017.005

Data wpływu: 01.08.2017

Data akceptacji: 14.09.2017

The Financial Police in Italy. The article aims to outline the organizational structure and competences of the Financial Police in Italy as one of the many police services in this country. Due to the lack of sufficient sources available in Polish, the work was prepared on the basis of those available in Italian-both legally binding and historical legal acts, as well as the official websites of the Financial Police and its museum, were used. Taking up the subject matter related to the organization of the Financial Police is justified by the entry into force of 1 March 2017 of the Act of 16 November 2016 about the National Treasury Administration because of the possibility of the future comparable presentation of services of similar competences operating in Poland and Italy.

Keywords: financial police, Italian Republic, organization, competences

Le osservazioni generali sulla Guardia di Finanza italiana. Il presente articolo affronta il tema della struttura e delle competenze di un corpo di polizia italiana, la Guardia di Finanza. A causa della mancanza di fonti disponibili in polacco il contributo è stato preparato sulla base di quelli disponibili in italiano. L'affrontare l'argomento relativo all'organizzazione della Gurdia di Finanza italiana è interessante alla luce del fatto che il 1 marzo 2017 è entrata in vigore la legge polacca del 16 novembre 2016 sull'Amministrazione Nazionale del Tesoro. La legge impone la fusione dell'amministrazione doganale,

* Marta Sagan - asystent, Zakład Prawa Finansowego, Wydział Prawa i Administracji, Uniwersytet Rzeszowski. 
amministrazione fiscale e autorità di controllo finanziario che finora operavano separatamente. Di conseguenza, in futuro sarà possibile confrontare le problematiche presentate e gli aspetti pratici delle attività condotte delle autorità italiane e polacche.

Parola chiave: Guardia di Finanza italiana; corpo di polizia italiana; controllo finanziario.

Zagadnienia związane z organizacją policji we Włoszech nie były dotychczas szeroko komentowane w polskiej literaturze przedmiotu ${ }^{1}$. W związku z powyższym uzasadniona wydaje się być próba przedstawienia w zarysie informacji dotyczących organizacji i kompetencji Straży Skarbowej jako jednej z wielu służb o uprawnieniach policyjnych w Republice Włoskiej. Ze względu na bardzo niewielką dostępną ilość pozycji bibliograficznych w języku polskim odnoszących się do poruszanej tematyki tekst został przygotowany przede wszystkim w oparciu o źródła w języku włoskim dostępne w internecie - akty prawne regulujące status i funkcjonowanie Straży Skarbowej, oficjalny portal korpusu, bogatą stronę internetową jej muzeum historycznego oraz informacje prasowe publikowane w uznanych włoskich dziennikach. Walorem naukowym niniejszej pracy jest tłumaczenie specjalistycznych tekstów prawniczych oraz aktów normatywnych na język polski.

Podjęcie tematyki związanej z organizacją i funkcjonowaniem Straży Skarbowej we Włoszech wydaje się ponadto uzasadnione wejściem w życie 1 marca 2017 r. większości przepisów ustawy z dnia 16 listopada 2016 r. o Krajowej Administracji Skarbowej ${ }^{2}$. Regulacja ta zakłada połączenie dotychczas działających w Polsce oddzielnie służb: celnej, podatkowej i kontroli skarbowej, w jeden skonsolidowany aparat skarbowy ${ }^{3}$. W związku z powyższym w przyszłości możliwe będzie porównawcze ujęcie przedstawionych zagadnień i skonfrontowanie praktycznych aspektów działalności organów włoskich oraz polskich w podobnym zakresie.

${ }^{1}$ Na temat policji we Włoszech por. B. Hołyst, Policja na świecie, Warszawa 2013; J. Jedynak, S. Krawczyk, Specjalistyczne formacje policyjne w Republice Włoskiej, „Ius et Administratio” 2005, nr 3; Idem, Włoscy żandarmi w służbie bezpieczeństwa publicznego, „Policja” 2005, nr 3.

2 Dz.U. 2016 poz. 1947.

${ }^{3}$ Liczne komentarze dotyczące wskazanej regulacji dostępne są w „Gazecie Prawnej“ pod adresem internetowym: http://www.gazetaprawna.pl/tagi/krajowa-administracja-skarbowa, (05.02.2017), zob. też: http://www.rp.pl/Opinie/302019915-Kogo-ustrzeli-policja-skarbowa--komentarz-Ewy-Usowicz.html\#ap-1, (05.02.2017). 


\section{PODSTAWOWE INFORMACJE}

Guardia di Finanza (oficjalnie używa się skrótu G. di F ${ }^{4}$, nieoficjlanie także GdF), czyli Straż Skarbowa ${ }^{5}$, jest formacją policyjną o organizacji wojskowej. W Republice Włoskiej istnieje wiele innych służb o uprawnieniach policyjnych, do których oprócz Straży Skarbowej zalicza się m.in. Korpus Karabinierów (Arma dei Carabinieri), Policję Państwową (Polizia di Stato), Policję Penitencjarną (Polizia Penitenziaria) oraz Korpus Państwowej Straży Leśnej (Corpo Forestale dello Stato). Każda z nich podlega bezpośrednio innemu ministrowi i są to odpowiednio ministrowie: Obrony Narodowej, Spraw Wewnętrznych, Finansów i Gospodarki, Sprawiedliwości oraz Rolnictwa. Ponadto w prowincjach działają jednostki Policji Prowincjonalnej (Polizia Provinciale), a w większych miastach spotkać można Policję Miejską (Polizia Municipale) ${ }^{6}$. Taki stan rzeczy w praktyce rodzi problemy z koordynacją poszczególnych służb.

Pierwowzór Straży Skarbowej utworzony został w Królestwie Sardynii w 1774 r. Straż Skarbowa stała się korpusem włoskim w XIX w. ${ }^{7}$ Rocznica jego powstania obchodzona była początkowo 5 lipca $^{8}$, a po 1965 r. została przełożona na 21 czerwca $^{9}$. Data ta związana jest z udziałem korpusu Straży Skarbowej w wygranej przez Włochów bitwie nad Piawą podczas I wojny światowej ${ }^{10}$.

Pod obecną nazwą Straż Skarbowa funkcjonuje od 2 czerwca 1946 r. ${ }^{11}$, a w okresach wcześniejszych, tj. od 13 maja 1862 r. do 7 kwietnia 1881 r. w Kró-

${ }^{4}$ Zgodnie z publikacją Ministerstwa Obrony nr 5876 z 2000 r. Abbreviazioni e sigle di uso autorizzato nell'Esercito, SME - Reparto Impiego delle Forze - Ufficio Dottrina Addestramento e Regolamenti.

${ }^{5}$ W tłumaczeniach na język polski nazwa Guardia di Finanza pojawia się jako Policja Finansowa, Policja Celna, Policja Skarbowa oraz Straż Skarbowa. W ocenie autora najbardziej odpowiednie jest ostatnie z wymienionych.

${ }^{6} \mathrm{http}: / /$ www.policja.pl/pol/aktualnosci/6244,dok.html, (02.01.2017).

7 Sam proces powstawania formacji policyjnych obejmował łączenie się zasobów militarnych państw sprzed zjednoczenia Włoch z należącymi do Królestwa Sardynii w okresie 18591861/1862r., dane za stroną internetową: http://www.treccani.it/enciclopedia/le-forze-armate_ (L'Unificazione), (02.02.2017).

${ }^{8}$ Dekret królewski z 3 stycznia 1926 r. nr 126, Approvazione del regolamento organico per la Regia guardia di finanza, art. 16, http://www.ficiesse.it/home-page/7455/pubblichiamo-i-vetusti-ma-tuttora-vigenti-regolamenti-della-guardia-di-finanza-risalenti-al-1926-e-1930, (02.01.2017).

9 P. Mecciarello (a cura di.), Dallo Judrio a Vittorio Veneto: i finanzieri nella prima guerra mondiale, Parma 1999, s. 24.

${ }^{10} \mathrm{http} / / / \mathrm{www} . t r e c c a n i . i t / e n c i c l o p e d i a / b a t t a g l i e-d e l-p i a v e \_(D i z i o n a r i o-d i-S t o r i a)$, (07.01.2017).

${ }^{11}$ W Rzymie od 1937 r. na Piazza Armellini mieści się muzeum historii Straży Skarbowej. 
lestwie Włoch jako Korpus Straży Celnej (Corpo delle Guardie doganali) ${ }^{12}$ oraz od 8 kwietnia 1881 r. do 1 czerwca 1946 r. pod nazwą Królewska Straż Skarbowa (Regia Guardia di Finanza) $^{13}$.

\section{PODSTAWY PRAWNE}

Ustawa z 7 stycznia 1929 r. ${ }^{14}$ przyznaje funkcjonariuszom korpusu Straży Skarbowej status funkcjonariuszy policji podatkowej powierzając im kontrolę i karanie nadużyć finansowych. Zgodnie z ustawą z 23 kwietna 1959 r. o organizacji Korpusu Straży Skarbowej ${ }^{15}$, podlega ona bezpośrednio Ministrowi Finansów i Gospodarki. Dekretem ustawodawczym ${ }^{16}$ z 19 marca 2001 r. $^{17}$ zredefiniowano i uporząakkowano kompetencje korpusu, wśród których należy zwrócić uwagę w szczególności na: pełnienie funkcji policji podatkowej i finansowej, dochodzeniowej, zapobiegnie i karanie przemytu, walka z unikaniem uiszczania należności publicznoprawnych oraz handlem substancjami odurzającymi, walka oraz zapobieganie przestępczości zorganizowanej, praniu brudnych pieniędzy, przeciwdziałanie finansowaniu terroryzmu oraz utrzymywanie porządku publicznego.

Dekret ustawodawczy z 19 sierpnia 2016 r. ${ }^{18}$, który wszedł w życie 13 września 2016 r. rozszerzył kompetencje formacji w działalności na morzu, znosząc

12 Ustawa z 13 maja 1862 r., Legge sull'Ordinamento delle Guardie Doganali, https://archivio.camera.it/resources/pu01/allegati/Istituzione_Guardie_doganali.pdf, (02.02.2017).

${ }^{13} \mathrm{http} / / /$ museostorico.gdf.it/visita-virtuale-del-museo-storico/piano-terra-del-museostorico/5-la-regia-guardia-di-finanza, (02.02.2017).

${ }^{14}$ Ustawa z 7 stycznia 1929 r. nr 4 Norme generali per la repressione delle violazioni delle leggi finanziarie, http://www.isaonline.it/mag/Legge004-1929.html, (23.01.2017).

15 Ustawa z 23 kwietnia 1959 r. nr 189 Ordinamento del Corpo della Guardia di FInanza, http://www.gazzettaufficiale.it/atto/serie_generale/caricaArticoloDefault/originario?atto.dataPubblicazioneGazzetta=2001-03-26\&atto.codiceRedazionale=001G0124\&atto.tipoProvvedimento$=$ DECRETO $\%$ 20LEGISLATIVO, (23.01.2017).

16 Por. A. Gaca, Z. Witkowski, Podstawy ustroju konstytucyjnego Republiki Włoskiej, Toruń 2012, s. 246-247. We Włoszech przyjęto instytucję ustawodawstwa delegowanego ze strony parlamentu na rzecz rządu. W przypadku istnienia ustawy delegującej rząd, w granicach ustalonych przez parlament, wydaje ustawy delegujące (leggi delegate) w formie dekretów ustawodawczych (decreti legislativi). Parlament ma swobodę zarówno w udzieleniu delegacji rządowi, jak i jej cofnięciu.

17 Dekret ustawodawczy z 19 marca 2001 r. nr 68 Adeguamento dei compiti del Corpo della Guardia di finanza, a norma dell'articolo 4 della legge 31 marzo 2000, n. 78, http://www.gazzettaufficiale.it/atto/serie_generale/caricaDettaglioAtto/originario?atto.dataPubblicazioneGazzetta=2001-03-26\&atto.codiceRedazionale=001G0124\&elenco30giorni=false, (25.01.2017).

${ }_{18}$ Dekret ustawodawczy z 19 sierpnia 2016 r. nr 177 Disposizioni in materia di razionalizzazione delle funzioni di polizia e assorbimento del Corpo forestale dello Stato, ai sensi dell'ar- 
dotychczas przysługujące w tym zakresie policji państwowej oraz karabinierom. Oznaczało to przyznanie uprawnień Straży Skarbowej w utrzymaniu porządku publicznego na morzu ${ }^{19}$. Biorąc pod uwagę powyższe, wymienić można m.in. następujące obszary działalności Straży Skarbowej: przestępstwa przeciwko administracji publicznej (przede wszystkim o charakterze gospodarczym i finansowym), nadużycia finansowe na szkodę instytucji Unii Europejskiej, podrabianie znaków towarowych, fałszerstwo walut, przemyt, handel substancjami odurzającymi, nielegalna imigracja, hazard, cyberprzestępstwa, lichwa, przeciwdziałanie przestępczości zorganizowanej, udział w utrzymaniu porządku i bezpieczeństwa publicznego.

\section{STRUKTURA ORGANIZACYJNA I KOMPETENCJE}

Pierwotna organizacja korpusu została zmieniona ustawą z 23 kwietnia 1959 r. $^{20}$. Jego struktura organizacyjna w późniejszym okresie uległa kolejnym modyfikacjom m.in. na podstawie dekretu Prezydenta Republiki Włoskiej z 29 stycznia 1999 r. ${ }^{21}$, co miało na celu osiągnięcie większej sprawności i efektywności działania przy zachowaniu ekonomii w działalności administracji publicznej. Kompetencje poszczególnych jednostek Straży Skarbowej zasygnalizowano łącznie ze szkicem struktury organizacyjnej.

Obecnie istnieje 6 komend międzyregionalnych (comandi interregionali) z siedzibami w Mediolanie, Wenecji, Florencji, Rzymie, Neapolu i Palermo. Podlega im 20 komend regionalnych (comandi regionali). Pełnią funkcje nadzorcze, kontrolne i koordynacyjne nad podległymi im działami technicznymi, logistycznymi i administracyjnymi, a także jednostkami operacyjnymi, które mogą funkcjonować zarówno jako jednostki zwykłe, jak i wyspecjalizowane. Należą do nich m.in. komendy prowincjonalne (comandi provinciali).

ticolo 8, comma 1, lettera a), della legge 7 agosto 2015, $n$. 124, in materia di riorganizzazione delle amministrazioni pubbliche. http://www.gazzettaufficiale.it/eli/id/2016/09/12/16G00193/sg, (25.01.2017).

${ }^{19}$ Wiadomość dnia opublikowana 13.09.2016 r. na oficjalnym portalu internetowym regionu autonomicznego Valle d'Aosta pod adresem: http://www.regione.vda.it/notizieansa/details_i. asp?id=248446, (06.01.2017).

${ }^{20}$ Ustawa z 23 kwietnia 1959 r. nr 189 Ordinamento del corpo della Guardia di Finanza, http:// www.antiriciclaggioitalia.it/sites/default/files/wp-content/uploads/Legge-23-aprile-1959-n.189.pdf, (25.01.2017).

${ }^{21}$ Dekret Prezydenta Republiki z 29 stycznia 1999 r. nr 34, Regolamento recante norme per la determinazione della struttura ordinativa del Corpo della Guardia di finanza, ai sensi dell'articolo 27, commi 3 e 4, della legge 27 dicembre 1997, n. 449, http://gazzette.comune.jesi.an.it/44/3. htm, (7.01.2017). 
Warto zaznaczyć, że obok komend międzyregionalnych, specjalnymi kompetencjami wykorzystywanymi na terytorium całego kraju wyróżniają się liczne zespoły specjalne. Należą do nich sprawy dotyczące wpływów do budżetu państwa oraz budżetów wspólnot lokalnych, wydatków publicznych, karanie wspólnotowych nadużyć finansowych, nadużyć w zakresie budżetu Unii Europejskiej, przemytu, kontroli rozchodów budżetu państwa oraz budżetów wspólnot lokalnych, ochrona rynków finansowych i sektorów związanych z transgranicznym przepływem kapitału, pośrednictwem finansowym, lichwą, dyscypliną środków płatniczych, finansowaniem terroryzmu, ochroną oszczędności, a także sprawy popełnienia czynów zabronionych przewidzianych przez ustawy bankowe, o których stanowi dekret ustawodawczy z 1 września 1993 r. nr $385^{22}$ będący tekstem jednolitym ustaw mających za przedmiot sprawy bankowości i kredytów, dekret ustawodawczy z 24 lutego 1998 r. nr $58^{23}$ zawierający przepisy o pośrednictwie finansowym oraz Kodeks ubezpieczeń prywatnych ${ }^{24}$; działania skierowane przeciwko przestępczości zorganizowanej, ochrona rynku, w szczególności w zakresie czynów niedozwolonych przeciwko gospodarce publicznej, przemysłowi i handlowi, gospodarczo-finansowe czyny niedozwolone popełniane w cyberprzestrzeni oraz przestępstwa popełniane przez hakerów i crackerów ${ }^{25}$; działania z zakresu prewencji oraz zwalczania korupcji oraz przeciwko innym formom popełniania czynów zabronionych w administracji publicznej; sprawy związane z ochroną znaków towarowych, licencji oraz własności intelektualnej, bezpieczeństwem i legalnością produktów, piractwem utworów audiowizualnych i informatycznych.

Ciekawym elementem omawianego korpusu jest Pogotowie Alpejskie Straży Skarbowej (Soccorso alpino della Guardia di Finanza) powstałe w 1965 r. Dzieli się na podzespół zarządzający w Komendzie Głównej, pododdział techniczny oraz Szkołę Alpejską w Predazzo, a także 26 stacji w rejonach górskich. Stacje podlegają w zakresie operacyjno-technicznym Szkole Alpejskiej, a w zakresie dyscypliny i zatrudnienia - komendom prowincjonalnym. W Pogotowiu Alpejskim Straży Skarbowej pełni służbę 275 funkcjonariuszy wykwalifikowa-

${ }^{22}$ Dekret ustawodawczy z 1 września 1993 r. nr 385 Il testo unico delle leggi in materia bancaria e creditizia, http://def.finanze.it/DocTribFrontend/getAttoNormativoDetail.do?ACTIO$\mathrm{N}=$ getSommario\&id=\{64F84178-A943-4A2C-9231-BCC2A9B02541 $\}$, (8.01.2017).

${ }^{23}$ Dekret ustawodawczy z 24 lutego $1998 \mathrm{r}$. nr 58 Testo unico delle disposizioni in materia di intermediazione finanziaria, https://www.ecb.europa.eu/ecb/legal/pdf/it_draft_law_con_1998_3. pdf (08.01.2017).

${ }^{24}$ Dekret ustawodawczy z 7 września 2005 r. nr 209, Codice delle assicurazioni private, http:// www.consob.it/main/documenti/Regolamentazione/normativa_ln/dlgs209_2005.htm, (08.01.2017).

${ }^{25}$ Osoba włamująca się do sieci komputerowych w celach niezgodnych z prawem; osoba zajmująca się łamaniem zabezpieczeń aplikacji komputerowych, http://sjp.pl/crackera, (25.01.2017). 
nych do udziału w górskich akcjach ratunkowych ${ }^{26}$. W strukturze Straży Skarbowej istnieje także wyodrębniona gałąź szkoleniowa - Inspektorat szkoleniowy (Ispettorato per gli istituti di istruzione). Struktura szkół jest podobna do struktury Komend Ponadregionalnych. Mają one za zadanie sprawowanie koordynacji i kontroli nad szkołami podległymi w zakresie rekrutacji i przygotowania szeregowych oraz szkolenia i szkoleń specjalistycznych dla funkcjonariuszy i personelu. W strukturze straży skarbowej wyodrębnione są ponadto jednostki specjalne, do których należy m.in. centralna służba dochodzeniowa ds. przestępczości zorganizowanej (Il Servizio centrale di investigazione sulla criminalità organizzata, SCICO) powołana na podstawie zarządzenia $\mathrm{nr}$ 216093/310 z 10 lipca $1993 \mathrm{r}$. wydanego na podstawie ustawy nr 203 z 12 lipca 1991 r. Pilne środki dotyczące walki z przestępczością zorganizowaną i przejrzystości i sprawności działalności administracyjnej ${ }^{27}$. Do obszaru jej działania należą: zbieranie danych i informacji dotyczących działalności dochodzeniowej Straży Skarbowej skierowanej przeciwko przestępczości zorganizowanej, analiza zebranych danych w celu zindywidualizowania i wypracowania metodologii śledczych oraz wskazania kierunków działalności technicznej i operacyjnej GICO; utrzymywanie kontaktów, na poziomie centralnym, z Krajowym Prokuratorem ds. zwalczania mafii oraz współpraca z GICO, wymiana informacji z odpowiadającymi Służbami centralnymi sił policyjnych, z DIA, a także z organami i służbami policji śledczej oraz, za pośrednictwem Komendy Głównej, z organami policji zagranicznej; zapewnienie wymiany informacyjnej między poszczególnymi siłami policyjnymi dla celów prewencji oraz karania przestępstw porwania osób dla okupu; zapewnienie wsparcia techniczno-logistycznego GICO, a także zabezpieczanie pomocy operacyjnej GICO poprzez zaangażowanie personelu o specjalistycznych kwalifikacjach dla wykonywania czynności policji śledczej.

Kolejną jednostką specjalną jest grupa dochodzeniowa ds. przestępczości zorganizowanej (Gruppo d'investigazione sulla criminalità organizzata, GICO). Zajmuje się wyłącznie sprawami przestępczości zorganizowanej, takimi jak pranie brudnych pieniędzy, terroryzmem w skali krajowej oraz międzynarodowej, porwaniami, przeciwdziałaniu handlowi narkotykami i przemytowi na dużą skalę. Jej funkcjonariusze, prowadząc operacje, wyposażeni są w specjalne uprawnienia, np. tajnych agentów oraz możliwość przeprowadzania prowokacji.

${ }^{26}$ http://www.gdf.gov.it/chi-siamo/organizzazione/specializzazioni/soccorso-alpino/chi-siamo/cenni-storici, (11.01.2017).

${ }^{27}$ Dekret ustawodawczy ze zmianami przekształcony w ustawę: Ustawa z 12 lipca $1991 \mathrm{r}$. nr 203, http://www.comune.jesi.an.it/MV/leggi/l203-91.htm, (25.01.2017). 
Warto wspomnieć także o Antynarkotykowych Grupach Operacyjnych (Gruppi Operativi Antidroga, GOA), które są elementem każdej GICO. Działalność grup $G O A$ jest skierowana przeciwko handlowi narkotykami na dużą skalę oraz zarówno krajowemu, jaki międzynarodowemu przerzutowi substancji odurzających.

Z kolei oddziały antyterrorystyczne i szybkiego reagowania (Reparti antiterrorismo e pronto impiego, ATPI) są to oddziały wysoko wyspecjalizowane, zajmujące się głównie pomocą innym jednostkom w trakcie operacji o podwyższonym ryzyku. Mogą być także używane w sytuacjach poważnego zagrożenia dla porządku publicznego. Zadania operacyjne przeciwdziałania terroryzmowi wykonywane przez ATPI związane są z nieustanną obecnością w terenie i polegają na dozorowaniu lotnisk, portów oraz innych miejsc uważanych za newralgiczne, a także szybkim reagowaniu, przez które rozumie się działania przeciwko nielegalnemu handlowi, ze szczególnym uwzględnieniem przestępczości zorganizowanej w zakresie przemytu, handlu substancjami odurzającymi, bronią oraz nielegalnej imigracji, udział, wraz z innymi siłami policyjnymi, w utrzymaniu bezpieczeństwa i porządku publicznego oraz interwencje w przypadkach jego zakłócenia, podejmowanie czynności na podstawie zgłoszeń pod $\mathrm{nr} 117$, będący telefonem alarmowym policji skarbowej, udział w międzynarodowych misjach pokojowych.

Ustawa z 3 czerwca 2010 r. ${ }^{28}$ regulująca sposób powołania Komendanta Głównego Straży Skarbowej oraz działania militarne podejmowane przez formację w przypadku wojny oraz w misjach wojskowych za granicą, do której uchwalenia przyczyniły się ówczesna parlamentarna Komisja Obrony oraz Komisja Finansów, stanowi, że Komendant Główny jest wybierany spośród oficerów w stopniu generała broni ${ }^{29}$. Nominacja następuje dekretem Prezydenta Republiki Włoskiej na podstawie uchwały Rady Ministrów podjętej na wniosek ministra właściwego ds. finansów za zgodą ministra właściwego ds. obrony ${ }^{30}$.

${ }^{28}$ Ustawa z 3 czerwca 2010 r. nr 79 Norme in materia di nomina del Comandante generale del Corpo della guardia di finanza e di attivita' di concorso del medesimo Corpo alle operazioni militari in caso di guerra e alle missioni militari all'estero, http://www.gazzettaufficiale.it/eli/ id/2010/06/03/010G0102/sg, (08.01.2017).

2929 kwietnia 2016 r. nowym Komendantem Głównym Straży Skarbowej został Giorgio Toschi http://www.gdf.gov.it/eventi/anno-2016/il-generale-giorgio-toschi-e-il-nuovo-comandantegenerale-della-guardia-di-finanza, (08.01.2017).

${ }^{30}$ Art. 4 ust. 1 ustawy z 23 kwietnia 1959 r. nr 189. 


\section{SYMBOLIKA I UMUNDUROWANIE}

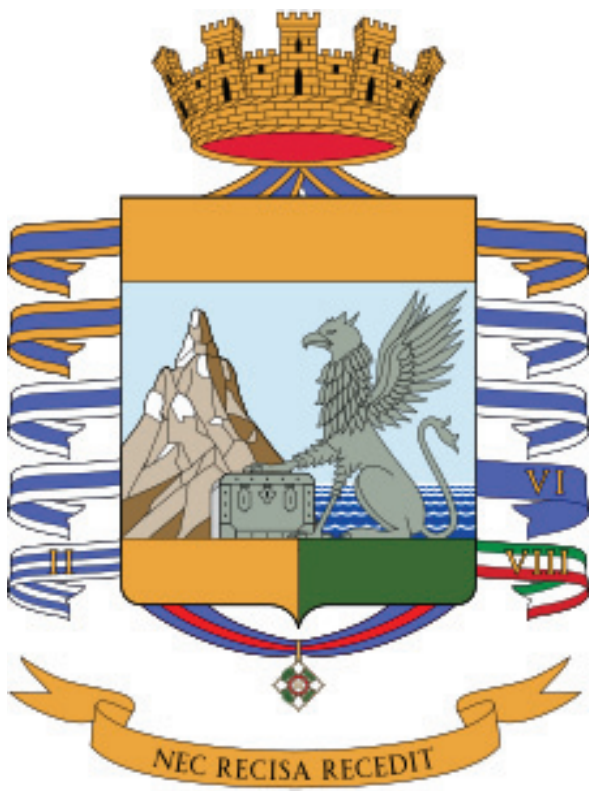

Źródło grafiki: https://it.wikipedia.org/wiki/Guardia_di_Finanza, (22.06.2017).

Od 1949 r. na godle Straży Skarbowej występuje gryf. Na mocy dekretu Prezydenta Republiki Włoskiej został przyznany korpusowi w celach reprezentacyjnych symbol „srebrnego gryfa stojącego na tylnych nogach, kładącego przednią prawą łapę na skrzyni”. Warto zwrócić uwagę na fakt, że połączenie sylwetki gryfa z kolorem złotym w XX w. heraldyce odnosi się do postaci i społeczeństw związanych w pewien sposób z finansami ${ }^{31}$. Symbolem gryfa posługiwano się od wielu wieków. Ślady znajdziemy w sztuce egipskiej, indyjskiej, perskiej, a także w greckiej i rzymskiej ${ }^{32}$.

W 2007 r., po długim okresie badań i prób, Policja Skarbowa otrzymała nowy wzór munduru, jaki wprowadzany był stopniowo i zastąpił dotychczasowo używany koloru szarozielonego. Zmiana podyktowana była wyrokiem Regionalnego Sądu Administracyjnego, w którym stwierdzono, że mundur Straży Skarbowej nie odróżnia się dostatecznie krojem ani kolorem od używanego przez Korpus Państwowej Straży Leśnej. Jako formacji starszej Straży Leśnej przyznano prawo korzystania z dotychczasowego wzoru umundurowania i zobligowano Straż Skarbową do jego zmiany. Nowa wersja używana jest obligatoryjnie przez wszystkich funkcjonariuszy od 1 marca $2011 \mathrm{r}^{33}$ Odcień szarości został zmieniony na ciemniejszy, do munduru dodano fioletowy krawat.

31 Por. szerzej P. Gwyn-Jones, The Art of Heraldry, Londyn 1998.

${ }^{32} \mathrm{http}: / / \mathrm{www}$. treccani.it/enciclopedia/grifone/, (07.01.2017).

${ }^{33}$ Finanzieri, vecchia divisa addio, „Corriere della Sera”, artykuł z 27 marca 2011 r., http://www.corriere.it/cronache/11_marzo_27/finanza-uniforme_2ceb6904-5854-11e0-8955-c490be50f429.shtml, (06.01.2017). 


\section{PODSUMOWANIE}

Korpus Straży Skarbowej we Włoszech to dobrze wyposażona, sprawnie działająca formacja o długoletniej tradycji i bogatej historii. Z biegiem czasu struktura terytorialna, a co za tym idzie, także organizacyjna oraz przyznawane kompetencje i zadania były modyfikowane i sukcesywnie dostosowywane do zmieniających się warunków zewnętrznych, odpowiadając tym samym rzeczywistym potrzebom kształtującego się i zmieniającego państwa. Warto podkreślić, że już na etapie przygotowywania do podjęcia służby przyszli funkcjonariusze kształceni są kierunkowo pod kątem wykonywania zadań należących do zakresu działania Policji Skarbowej, co umożliwiają własne szkoły i jednostki zajmujące się ich przygotowaniem. W późniejszym okresie funkcjonariusze uczestniczą w doskonaleniu zawodowym. Przekłada się to na wysoki poziom specjalizacji poszczególnych jednostek w ramach korpusu i efektywność w wykonywaniu zadań.

\section{BIBLIOGRAFIA:}

Gaca A., Witkowski Z., Podstawy ustroju konstytucyjnego Republiki Włoskiej, Toruń 2012.

Gwyn-Jones P., The Art of Heraldry, Londyn 1998.

Hołyst B., Policja na świecie, Warszawa 2013.

Jedynak J., Krawczyk S., Specjalistyczne formacje policyjne w Republice Wtoskiej, „Ius et Administratio“ 2005, nr 3.

Jedynak J., Krawczyk S., Włoscy żandarmi w służbie bezpieczeństwa publicznego, „Policja“" 2005, nr 3.

Mecciarello P. (a cura di), Dallo Judrio a Vittorio Veneto: i finanzieri nella prima guerra mondiale, Parma 1999. 